\title{
PRESENCE OF SUSTAINABILITY APPROACHES IN FASHION DESIGN ACADEMIC CURRICULA: EVIDENCES FROM SOUTHERN EUROPE
}

\author{
A. Marques, E. Sousa, A. Broega \\ University of Minho (PORTUGAL)
}

\begin{abstract}
This paper will present an analysis of academic offers and curricula in Portugal, Spain, France and Italy (four countries from Southern Europe with an important fashion industry) in fashion and design courses: bachelor, master and PhD programs. The discussion will be focused in several aspects of the topics "sustainability", the main one, "eco-design", "etic fashion", "slow fashion", "green products", "social design" or "slow design". The way how these European universities communicate these topics to their students will be also analyzed and described. In the last years social media and websites became the main channels to communicate with the new consumers and to the future candidates that will applying to new jobs in fashion industries, and they are much more aware to sustainability topics. This qualitative research was developed during six months. The methodology followed during the research was documental analysis, using different sources, and also was done the follow up of the Higher Education Institutions' webpages in these four cases (countries). The observations and results can be helpful to understand how each country is approaching the sustainability in academic curricula and redesign or redefine new curricula or new courses, focused on sustainability, and to define learning strategies and tools to prepare future professionals of fashion industry more conscious to sustainable topics.
\end{abstract}

Keywords: Academic curricula, sustainability, design skills, fashion industry.

\section{INTRODUCTION}

Sustainability is a key topic in the academic research in the most developed and advanced economies. The natural resources are increasingly scarce, and their depletion will have a tremendous impact on the environment and climate changes [1]. It is urgent to promote a new attitude and behaviour in the consumers and in the industries stakeholders to keep a light on at the end of the tunnel. Earth, this fantastic planet, is unique and is our home!

The fashion industries (textile, clothing and footwear) are responsible for a big environmental impact and have an enormous footprint in several countries [2]. It starts with the raw materials (natural, artificial and synthetics), water consumption, the using of dyes and other chemical products, the transportation from far suppliers and producers to the main markets, and finally the "Fast Fashion", the main and last "poison" from fashion industries in the last decades.

In Southern Europe (Portugal, Spain, France and Italy) there are several universities and polytechnics - Higher Education Institutions (HEI) -, public and private, whit fashion and design courses in different levels: bachelors, masters and doctoral programs. The portfolio goes from undergraduate (graduate) and postgraduate courses, according the needs and demands from the industry and also from the future professionals of fashion industries. So, it is very important to prepare the new fashion professionals, designers, engineers, technicians, researchers, marketers and teachers to these new scenarios and challenges [3]. Also, these countries are very important players in the fashion industries and they are "new direction's makers" to other followers. Furthermore, Paris, Milan and Barcelona are global fashion capitals'. But there are "sustainability" courses, approaches or topics in fashion design academic curricula in these European countries? Are they preparing the new professionals with this skills and tools to face these new challenges?

The textile and clothing (T\&C) industry is very important in Italy, Portugal, France and Spain. Italy is the European country with more employment in T\&C - more than 400.000 workers - and also with the bigger annual turnover, according the last official data from Euratex. Italy and France have the most important brands in luxury and premium fashion clothes, guiding the trends around the world. Paris and Milan are the most important fashion capitals and hosting the most creative fashion designers. Spain has the biggest world retailer in "fast fashion" (Inditex group located in Coruna) and Portugal is 
also an important player is this industry, with more than 137.000 workers, with an annual turnover of 7.350 million euros and exports of 5.237 million euros [4].

In this article, the Portuguese HEI will be analyzed with more detail because the authors did a direct contact with the graduate and postgraduate directors in these public $\mathrm{HEI}$ and checked the sustainability approaches in their curricula.

\section{METHODOLOGY}

The methodological approach to this research was defined considering the specificities of the T\&C sector, the educational national systems from the different countries and the proposed research objectives. The research methodology can be quantitative or qualitative: the qualitative analysis is often mentioned as the most recommended when the researcher wants to study a small sample of entities or organizations and the study is focused on a theme, subject or sector [5],[6].

A qualitative research was prepared to obtain the necessary data, using document analysis and research on the institutional websites [6]. The triangulation of data of the Portuguese Higher Education Institutions was very important to define and identify the strategy of each academy in sustainability approaches.

The HEI with fashion design courses from Spain, France and Italy considered to be described in this paper were selected from the Fashion Schools participants in the International Fashion Conference "Design and Sourcing in Europe", Porto, 12 December, 2017. Intentional or purposive sampling is an option very interesting when the researcher wants to study a particular phenomenon, fact or aspect that will serve better your research or "will best enable you to answer your research question(s) and to meet your objectives". [5].

The complete analysis of all the academic options in Fashion Design in these Southern European countries, undergraduate and postgraduate, private and public, will be the next research to prepare a European project to submit to Erasmus+.

\section{GRADUATE AND POSTGRADUATE COURSES IN FASHION DESIGN}

Fashion Design is a recent course in several European universities and appears in some of them after the Bologna process, as it is the Sustainability approaches in many HEl. Table 1 shows the general overview with Fashion Design courses and Sustainability topics or Curricular Units (CU) in the Southern European countries (Table 1).

Table 1. Fashion Courses in Southern Europe

\begin{tabular}{l|c|c|c}
\hline \hline \multicolumn{1}{c|}{ COUNTRY } & Fashion Courses & $\begin{array}{c}\text { Level } \\
\text { EFQ }\end{array}$ & $\begin{array}{c}\text { Topics/Curricular Unit } \\
\text { Sustainability }\end{array}$ \\
\hline Portugal & 6 & 6 & 2 \\
\hline & 6 & 7 & 1 \\
\hline Spain & 1 & 8 & 1 \\
\hline Italy & 14 & $6 / 7 / 8$ & 4 \\
\hline France & 18 & $6 / 7 / 8$ & 4 \\
\hline \hline
\end{tabular}

\subsection{Portugal}

The public fashion design courses are quite new in Portugal. In the last millennium, the focus in the higher education of fashion industry was the engineering courses, whether in textiles or in clothing. After a difficult economic period in the Portuguese textile and clothing sector (between 2004 and 2010), the young students decided to apply to other engineering options and the candidates decreased significantly in all the HEI with this specialization in T\&C. 
In the Portuguese HEI with specialization in fashion design there are four public organizations: University of Minho; University of Beira Interior; Faculty of Architecture of University of Lisbon; and Polytechnic Institute of Castelo Branco. There are others Portuguese private HEI with specialization in fashion design: ESAD in Matosinhos, IADE - Universidade Europeia and LSD - Lisbon School of Design, both located in Lisbon.

\subsubsection{University of Minho}

Fashion Design academic degrees offered by University of Minho are in the three EQF levels: Bachelor (EQF 6); Master (EQF 7) and Doctoral program (EQF 8). The University of Minho has created the Bachelor in Fashion Design (BFD) in 2006/2007, under the Bologna framework to the European Polytechnics and Universities. Nowadays, there are around ninety students registered in the three years of the course in BFD. There are two Masters programs under the supervision and scientific coordination of the Textile Department and also from the Centre for Science and Textile Technology (2C2T): Master in Fashion Design Communication and Master in Design and Marketing of Textile Product, Clothing and Accessories.

Minho University has a PhD program in Fashion Design, in collaboration with University of Beira Interior. Despite some researchers and investigation projects are already on track to study sustainability concepts, processes, advanced materials and applications in T\&C, in the academic curricula of the bachelor and master there's no Curricular Units or modules related with sustainability and fashion ethics. Doctoral program in Fashion Design has one Curricular Unit in "Option Group Advanced Courses", named Fashion and Ethics in the first year. It is one approach to the sustainability items, focused only in the social aspect of sustainability.

\subsubsection{University of Lisbon - Faculty of Architecture}

The Faculty of Architecture of University of Lisbon is the oldest Portuguese university with Fashion Design courses. There are two academic levels available to the candidates: Bachelor in Fashion Design; Master in Fashion Design; and Master in Textile and Clothing Design.

After a simple and clear analysis of the university website, can be identified in the Masters in Fashion Design a curricular unit called "Fashion and Sustainability", taught in the $2^{\text {nd }}$ semester of the $1^{\text {st }}$ year.

Description of the Curricular Unit: "Fashion and Sustainability - Understanding the relationship between fashion and sustainability by presenting initiatives introduced by the fashion industry to reduce harmful effects on the environment. Developing responsible awareness by exploring various emerging concepts such as ecofashion, zero waste and slow fashion, applied to the design of clothing, accessories and textile materials".

\subsubsection{University of Beira Interior}

University of Beira Interior (UBI) is located in the city of Covilhã, district of Castelo Branco. The region of Covilhã is an important cluster textile, with specialization in wool fabrics and men's suits clothing.

UBI has Bachelor degree in Fashion Design and has a Curricular Unit in "Sustainable Fashion Design". This CU is taught in the $2^{\text {nd }}$ semester of the $2^{\text {nd }}$ year. The Master's Fashion Design hasn't any Curricular Unit related with Sustainability, Ethics or Circular Economy.

As it was highlighted before, the Doctoral program in association with University of Minho, PhD in Fashion Design, has one Curricular Unit in "Option Group Advanced Courses", named Fashion and Ethics in the first year of the program.

\subsubsection{Polytechnic Institute of Castelo Branco}

The Polytechnic Institute of Castelo Branco is located $60 \mathrm{kms}$ far from Covilhã and his University of Beira Interior. The educational offer in Fashion Design courses is Bachelor in Design of Fashion and Textile, and Master in Design of Clothing and Textile.

On the second semester of the second year of Bachelor in Design of Fashion and Textile, there is a Curricular Unit with 3,5 ECTS named "Sustainability in Fashion". 


\subsection{Other southern European countries}

As it was said before, this analysis will focus mainly in some academic courses in Fashion Design from European HEI that participate in the International Fashion Conference "Design and Sourcing in Europe".

\subsubsection{Italy}

POLIMODA is one of the most important fashion school in Italy and Europe. It has undergraduate and postgraduate programs across the areas of Fashion Design, Fashion Business, Art Direction and Design Management. The three or four year undergraduate courses available are Fashion Technology, Leather Technology, Fashion Design, Business of Fashion, Fashion Marketing Management, Fashion Luxury Management, Fashion Art Direction and Fashion Design Management. Postgraduate programs has the duration of nine months and the candidates can chose between Collection Design, Accessories Design, Fashion Design, Fashion Store Concepts, International Fashion Business, Fashion Brand Management, Luxury Business, Fashion Marketing \& Communications, Fashion Styling, Fashion Trend Forecasting, Creative Direction and, finally, Fashion Buying \& Product Management. POLIMODA has also seasonal short programs (one month duration) with twenty two different options starting in March, July, September and December [7]. The analysis of POLIMODA study plans of each option in undergraduate or postgraduate shows that only International Fashion Business (postgraduate course) has "Fashion ethics" topic in the course module Fashion Business Management. Among another courses' options cannot find any approach to the sustainability or circular economy.

\subsubsection{Spain}

IED Madrid was in the International Fashion Conference representing Spain and is member of educational group Istituto Europeo di Design-IED with Fashion Schools in Italy, Spain and Brazil.

In the "Programa Europeo de Doble Título en Deseño de Moda + Fashion Stylist", with a duration of four years, there is in the first semester of the first year a module named "Ecodeseño". The content of this module is described as: "Introduction to sustainability by addressing global issues from the triple crisis (economic, social and environmental) through sustainability indicators to reach the concept of sustainable development".

The Master program in Fashion Design, with a duration of nine months, has a topic named "Sustainability" in the Module of Base Contents. This topic appears also in other Master courses as it is the case of Master in Direction and Management of Fashion Companies.

\subsubsection{France}

ESMOD France is one of the first Fashion School in the world, founded in 1841, before the creation of the "La Chambre Syndicale de la Haute Couture" in 1868. It has five Fashion Schools in France and has graduate and postgraduate programs and is ranked as one of the first French Fashion Schools in specialized magazines.

The ESMOD Fashion Design \& Creation has the Designer Fashion Designer course. In the third year the students do the Specialization, Personal Collection and Study Report with 60 ECTS and the description on the webpage is: "During this year, students first learn about the style and productrelated codes that characterize their specialization that they can then apply to their personal end-ofyear collection. Students also have the chance to express their creativity in one of the following skills: dyeing workshop, lace, graphic design, embroidery, sustainable development, leather, fur and hand knitting".

Sustainable development is included in the skills to the future professionals from ESMOD, as other necessary elements.

\section{RESULTS}

Fashion Design Schools in the Southern Europe are very important in the preparation of the future professionals in T\&C sector. The previous chapter shown the general overview of some of the most important Fashion Design schools and their relation with Sustainability and Circular Economy topics. 
As states ETP- European Technology Platform, Fibres Textile Clothing [8], "apart from traditional textile-related competences, new and transversal skills and qualifications will need to be acquired by employees. These relate to domains such as the digitisation of factories, workplaces and supply chains, the need to implement sustainability, circularity and resource-efficiency strategies in production and value chain management, international business competences due to the growing importance of export markets, cross-sectoral knowledge to serve customers in technical textile end markets. Special attention must be given to preservation and generational transfer of highly specialised competences and rare skills related to traditional material and manufacturing techniques, to niche applications of textiles or unique design skills (pp. 56)."

"All such skills and qualifications must become part of initial education curricula, but must also be provided in continuous vocational training programmes. The delivery of these VET programmes must be flexibly adapted to the realities of the SME-based industry. They must be available in proximity of the companies, ideally include practical hands-on sessions at technology-equipped training facilities, at digital learning labs or directly at the workplace. They must also make use of on-line and virtual learning concepts and technologies such as massive open online curses (MOOC) or the gamification of learning" [8].

But as states POLIMODA promotional book: "The concept of fashion displacement brings attention back to what really counts: the body and mind of young students, their gaze as it is, full of dreams and nightmares" [7].

John Elkington says in his book "Cannibals With Forks: the triple bottom line of the $21^{\text {st }}$ century" [9] there are Seven Revolutions for Sustainability: 1 - Markets; 2 - Values; 3 - Transparency; 4 - Lifecycle Technology; 5 - Partnership; 6 - Time; 7 - Corporate Governance. Considering that the Higher Education Institutions and their academic community - professors, students and staff -, are also consumers and members of live communities, they have to be the main engine to the future changes that has to occur in the fashion industry. Some countries are suffering the environmental impact of human activity in their lives and they are questioning the actions (or inaction) of some industries and consumers (fashion consumers) to face these problems [10].

\section{CONCLUSIONS}

Sustainability and Circular Economy are key topics in our common future. They are also critical issues in our lives. The next generations of consumers are much more aware to the impact of our behavior in the planet and they share this questions and concerns with their friends and communities, using the social media, blogs and the web. Most of them are today in the educational system and they will be placed, after their academic programs, in the fashion industry. The Higher Education Institutions in Europe start to put in their academic curricula some Curricular Units, topics or modules related with the Sustainability. But there is a long road ahead in many universities to achieve these goals of sustainable industry, fashion ethics and circular economy.

Circular economy is a new concept that starts to be in the "mouth of many important players" and stakeholders. In the European Textile Platform - ETP, this megatrend to the next decade is already assumed and written in their reports (pp.8): "Future Vision 2025 - By 2025 the textiles and clothing industry, including fibrebased materials, clothing, home and technical textiles, will be a strategic EU industry sector providing innovative and competitive products enabling personalised, adaptable and attractive solutions, integrating services for very diverse, informed and demanding consumers and business. It will operate according to a globalised and efficient circular economic model that maximises the use of local resources, exploits advanced manufacturing techniques and engages in cross-sectorial collaborations and strategic clusters. It will implement profitable and inclusive business models and attract skilled and talented entrepreneurs and employees".

It's time to the European Higher Educational Institutions implement in their undergraduate and postgraduate curricula these critical issues to our common future, a very near future indeed!

\section{ACKNOWLEDGEMENTS}

"This work is financed by FEDER funds through the Competitivity Factors Operational Programme COMPETE and by national funds through FCT - Foundation for Science and Technology within the scope of the project POCI-01-0145-FEDER-007136". 


\section{REFERENCES}

[1] W. McDonough \& M. Braungart, Cradle to Cradle: Remaking the way we make Things. New York: North Point Press, 2002.

[2] K. Slater, Environmental impact of textiles. Cambridge: Woodhead Publishing Limited and Textile Institute, 2003.

[3] K. Fletcher \& L. Grose, Moda e Sustentabilidade, design para a mudança. São Paulo: Editora SENAC, 2011.

[4] ATP - Associação Têxtil e de Vestuário de Portugal, Estatísticas da ITV [online]. Available at <http://www.atp.pt/gca/index.php?id=18> Accessed 07 May 2018

[5] M. Saunders, P. Lewis \& A. Thornhill, Research Methods for Business Students. $5^{\text {th }}$ edition. Harlow/Essex: Pearson Education Limited, 2009.

[6] J. W. Creswell, Research Design: qualitative \& quantitative approaches. Thousand Oaks: Sage Publications, 1994.

[7] POLIMODA, Become What You Are. Florence: POLIMODA, 2017.

[8] ETP-European Textile Platform, Towards a 4th Industrial Revolution of Textiles and Clothing. Brussels: EURATEX, 2016.

[9] J. Elkington, Cannibals With Forks: the triple bottom line of the $21^{\text {st }}$ century. Oxford: Capstone Publishing, 1997.

[10] A. Carvalhal, Moda com propósito: manifesto pela grande virada. São Paulo: Paralela - Estação das Letras e Cores, 2016. 